\title{
Understanding the Challenges and Opportunities of Micro, Small, and Medium Enterprises during COVID-19 Pandemic in Indonesia: A Systematic Review
}

\author{
Sudarmo \\ Sekolah Tinggi Ilmu Ekonomi Balikpapan, Indonesia \\ Corresponding author email: sudarmo@stiebalikpapan.ac.id
}

\begin{abstract}
Through this review, we will discuss the challenges and opportunities for MSMEs during a pandemic in Indonesia. This review examines the two sides of the small business experience, both difficulties, and opportunities. Understand these small business movers' experiences and success stories, a series of data collection; Google search, Google Scholar, ERIC Publications, and other data sources. Then we continue our in-depth analysis with a phenomenological approach until we get valid and reliable data in answering the questions of this systematic review study. Analyzing our data starts with understanding the study problem, coding the data, evaluating the data in-depth, and drawing data conclusions. The procedure and design of this systematic review study followed the guidelines for descriptive qualitative research methods. These findings include that most MSMEs have turned challenges into opportunities in sustaining their businesses after being hit by the Pandemic through the support of many parties, especially the government and experts. Thus the findings of this study are essential inputs to support MSMEs to survive and be sustainable.
\end{abstract}

Keywords---challenges, COVID-19, MSMEs, opportunities, review studies, understanding.

\section{Introduction}

When the COVID-19 Pandemic hit Indonesia, all human life sectors, like all other countries, experienced difficulties and sorrow (Putra et al., 2020; Hyder et al., 2020; Radic et al., 2020). There was no other choice at that time to reduce and break the pandemic chain; the Indonesian government was forced to take a policy by establishing a national Large-Scale Social Restriction. Since the restriction policy, the national economy has stalled and has followed a recession. Most of the businesses were closed, and part of the roads was in place. Along with the recession, layoffs have increased. Unemployment cannot be stopped; it spreads throughout the country. Luckily, there are still some people with a strong entrepreneurial spirit capable of turning disaster into luck. One of the entrepreneurs is that they are the movers of MSMEs in all types of small businesses. For example, the culinary and other small businesses are among the most resilient businesses facing pandemics and recessions (Morrish \& Jones, 2020).

This Pandemic that has been going on for more than a year has impacted the community's financial condition. However, many also rack the brains to improve their financial condition. One of them is by building a business using manageable approaches. In this way, business drivers can be relieved because they are still running their business but changing the strategy from in-place service is changed to take home and delivery options. These business options and strategies are in line with the concept of Heinonen \& Strandvik (2020) which is the reframing of business service innovations by eliminating the COVID-19 response policy as an effort to implement service innovations so that the business remains sustainable.

Talk about sustainable business in the dynamic era; the best solution is innovation in everything. Because anyone can survive if they want to make renovations to take advantage of opportunities even in difficult circumstances, an example that is easy to understand is if the government has a public restriction policy, all business activities will automatically stop. However, if there are people who want to change the method (innovation), they can continue the 
way of business offline to online, then everyone will be able to open their business quickly, for free, anywhere, and anytime. Because entrepreneurs have to change ways, consumers continue to change; that is, they do not want to risk fines with government regulations to respond to COVID-19 by changing the bell method; just going offline to a new and cool way via virtual. This method was studied by Dwivedi et al. (2020) through the study of the impact of the Pandemic on the study and practice of information management through transforming education, business, and life.

Challenges for MSMEs have been poorly hit since the Pandemic, even though these small and medium enterprises are the economic foundation of any development. The arrival of COVID-19 challenges that were considered small, but because they did not have the capital to protect their business from extraordinary disruption, they were almost destroyed from their survival. Many MSME studies in emergencies proposed solutions and approaches to overcome challenges to conquer business collapse through strategic innovation and business climate change. Eggers (2020) proposes a practical perspective in managing a situation of extraordinary vulnerability, namely through solutions to the three main challenges faced by MSME actors during the Covid-19 Pandemic in all major cities in the world.

Rizou et al. (2020) said the first challenge was in terms of supply. Since enacting policies that limit people's movement in almost all regions, many MSMEs have had difficulty getting raw materials. National policies that restrict people's movement disrupt logistical distribution make shipments ordered or purchased take longer to receive, even prices increase, and the quality of goods also decreases. The next challenge, according to Iwuoha \& Aniche (2020) said they have a cash flow issue. Many of these business people feel that their income has decreased because no customers have bought products since y the implementation of community restrictions and physical distancing policies. Small businesses also find it difficult to obtain capital loans. Their incomes have decreased, production costs are relatively expensive, plus the difficulty of accessing capital loans disrupts their cash flow. The third challenge is decreasing demand. Market uncertainty makes the demand for goods sold by MSMEs influential (Effendi et al., 2020; Zakiah, 2020; Amalia \& Suprayogi, 2019; Pindayi, 2017; Aslan, 2019).

As stated above, MSMEs are one of the sectors most affected by the Covid-19 Pandemic. However, this does not mean that these small businesses give up. The Pandemic is considered a challenge and an opportunity to test business actors' leadership in running their business. Kumar \& Ayedee (2021) stated that business people currently being hit by a pandemic need innovative solutions by adopting technology for SMEs. In line with that, many small business actors say that entrepreneurs should not be silent or even give up on the situation. Based on the two suggestions above, a pandemic is a challenge and an opportunity for the maturation of bustoctors' leadership to continue their business wheels to become stronger. Likewise, according to Papadopoulos et al. (2020) the use of technology is one of the solutions for digital adoption by small and medium enterprises at the time of COVID-19. With this solution, it is clear that their efforts have become practical; not only that so far, but the technological solutions for small businesses are also merely theoretical. There are at least three criteria for leadership in the context of MSMEs (Wisenthige \& Guoping, 2016; Bagudu et al., 2016; Syuhada \& Gambett, 2013). First clever. Company leaders must be competent at seeing opportunities. The instinct to take advantage of this opportunity must be honed and trained as often as possible. The second is hunger.

Be an SME, people who want to eat as much as possible. Self-development and efforts must continue. Dissatisfaction with this one achievement will continue to plague. Furthermore, Kottika et al. (2020) small businesses can survive this challenge. What managers can learn from SMEs who have survived the Greek economic crisis is reorganizing their management and marketing to adapt to the COVID-19 era. Because this is not a hard feeling but a challenging time and simultaneously makes this an opportunity for change. This third key is often an obstacle for some Indonesians. This attitude is considered to be able to hinder business actors from developing their business. Whether or not entrepreneurship can be seen from the three criteria. If there are three, that is the capital to survive the Pandemic. Likewise, Islam et al. (2021) configure a blueprint for Malaysian SMEs to survive through the COVID-19 crisis and its opportunity challenges. The reinforcement of the Quadruple Helix Innovation Model. They added that most businesses in Indonesia are on the scale of MSMEs, meaning that these small businesses will significantly affect other people; this sector is vital in supporting the national economy (Khanzode et al., 2021; Samantha, 2018; Bernroider, 2002; Gunawan et al., 2019).

As stated above, MSMEs are one of the sectors most affected by the Covid-19 Pandemic. However, this does not mean that these small businesses give up. The Pandemic is considered a challenge and an opportunity to test business actors' leadership in running their business. Kumar \& Ayedee (2021) stated that business people currently being hit by a pandemic need innovative solutions by adopting technology for SMEs. In line with that, many small business actors say that entrepreneurs should not be silent or even give up on the situation. Based on the two suggestions above, a pandemic is a challenge and an opportunity to automate business actors' leadership to continue their business wheels to become stronger. Likewise, according to Papadopoulos et al. (2020) the use of technology is one of the solutions for digital adoption by small and medium enterprises at the time of COVID-19. With this solution, it 
is clear that their efforts have become practical; not only that so far, but the technological solutions for small businesses are also merely theoretical. There are at least three criteria for leadership in the context of MSMEs.

First clever. Company leaders must be competent at seeing opportunities. The instinct to take advantage of this opportunity must be honed and trained as often as possible. The second is hunger. According to Mughni, several strategies can be carried out by MSME actors to survive in difficult situations. Each MSME, Suci (2017) has different characteristics. This means that different treatment for each small business is a necessity. However, they have one thing in common, business actors must make every potential an active development force. Sugiri (2020) efforts to save micro, small and medium enterprises from the impact of the Covid-19 Pandemic is that they must focus on business in management. They must be adopted with new media-based innovations and sustainable management and finance studies.

In an era of pandemics like this, it has never happened before. For them, this business world is an adaptation in a completely new situation, and they must work seriously. According to their expert advice, innovation is necessary and must continue to be explored by small business people. Small business experts agree that one of the essential things in a crisis is leadership and reputation. In other conditions, such as post-pandemic, business people need to be literate in the digital world. The times have forced business actors to continue to change. However, according to many literary sources, this is not enough. All entrepreneurs, big or small, need to run their business based on study and development data. The current era requires data and digitalization to engage businesses with all the risks, from challenges to opportunities (Leeflang et al., 2014).

Studies seeking a new understanding of small business actors' challenges and opportunities are critical do consider that the government and business actors must be able to see opportunities and think long-term in dealing with the current Pandemic. At least everyone will see that the economic development continues to decline, but with the still active activity of small businesses, it is confident that the Indonesian economy's optimistic predictions will increase. Indonesia and several other developing countries still hope to rise from an economic recession due to the pandemic response. This is in line with the study of Kuckertz et al. (2020) that, let alone continue the old business, new startup businesses can still run in times of crisis. Most urgent to think about is how all governments respond quickly to the COVID-19 Pandemic with its impacts and consequences. Thus the prediction of a recession will fall from the range of 5 percent to 2 percent at the end of 2021.

Although the recession due to the Pandemic has brought a severe shock to the national economy, the current situation and future predictions also have opportunities and hopes that not all business sectors collapse in the pandemic era (Blandina et al., 2020). For example, there are sectors related to a business pandemic that has improved. Call it the medical and health sector, online trade or e-commerce, to fast-moving consumer goods such as drugs, electronic goods, food products, packaged beverages, and the telecommunications and internet service industry. The challenge that remains to be faced is the currency exchange rate is expected to be maintained due to its impact on selling prices. Opportunities and opportunities must be understood collectively both from the point of view and application in the real economy sector, such as MSMEs (Endraswati, 2020). Our study wants to show the government and small business actors in the community that the COVID-19 crisis must be used as momentum in running people's businesses better. The public must understand and sustain surviving and sustaining through current economic studies and a new post-pandemic framework. This study's findings are where we want to invite business people to think long-term ahead with opportunity readiness and see this as a new challenge so that their businesses will continue to grow after entering the average era (Soetjipto, 2020).

\section{Method}

The study of a new understanding of small business people's opportunities and challenges in facing challenging times due to national policies responding to the COVID-19 Pandemic is very relevant. So for that, we have carried out a systematic review of the literature and several scientific publications. We have conducted a systematic review with the first step, namely clearly understanding the questions and objectives of this SMES study. Then we started an indepth analysis involving a coding system, critical evaluation before concluding to find answers that meet validity and reliability. A study involves systematic and explicit review methods to identify economic issues affected by the Pandemic, select and sort data, and critically assess relevant review results. Finally, we collect data as new understanding findings because our study suggests that secondary data becomes the primary data through searching Google Scholar, ERIC publications, and other Google search engines during the Pandemic. The design and procedure of this study follow the guidelines for the findings of the relevant qualitative review. Bernard et al. (2016) 
in their study "Analyzing qualitative data: Systematic approaches" and Eriksson \& Kovalainen (2015) in their study "Qualitative methods in business research: A practical guide to social research."

\section{Result}

This section will present the results of a systematic review of 50 international publications that discuss the latest issues, challenges, and hopes that small business people have felt during their business in the Pandemic that has been almost a year old. This section explains the results, while our discussion will be presented in a discussion section after the study data report.

Dengada (2020) examines the challenges and opportunities of micro, small and medium enterprises in Gujarat, India, which has emerged as a very fiery and dynamic region in the Indian economy over the past fifty years. MSMEs provide enormous job vacancies at an almost lower cost of capital than extraordinary businesses. They also assist in industrializing ordinary things and opposing areas, as needed, reducing the impersonal nature of the environment, and ensuring a more equitable distribution of compensation and public wealth. Studies rely on fundamental and assistant data. Fundamental data for the assessment has been collected from the cases of 319 MSMEs in various districts in Gujarat. This study offers assistance for business improvement and a wave of progress. The results of these studies, in the same way, assist in balancing immediate regional improvement with rural progress as much as regaining support and linkages with exceptional units. The study results are divided into five parts; MSME capital assistance, management training, business evaluation, and sustainability welcome the new normal.

Meanwhile, Shafi et al. (2020) focus on the impact of the COVID-19 Pandemic on small businesses, which have been the economy's backbone. Nowadays, almost no one has survived the impact, and it is the medium-sized businesses working in Pakistan. This article plans to review the impact of the eruption on this MSME association, which also provides methodological recommendations to help MSMEs reduce business setbacks and survive the crisis. More than $66 \%$ of sharing efforts stated that they would not suffer if the lockdown continued for more than two months. Our disclosure checks are solid with previous assessments, and a wide variety of recommended actions have been proposed to drive the opposite effect of this explosion on MSMEs. Although this proposed technique's recommendations may not be satisfactory, this assessment will help them deal with difficulties.

Likewise, Diah et al. (2020) from Indonesia also focuses on understanding challenges and opportunities for small businesses in eastern Indonesia facing pandemics and the Normal Era. East area in Indonesia is one of the districts affected by the COVID-19 Pandemic. Small and Medium Enterprises (SMEs, for example, culinary associations, are areas of business that are generally affected. The implementation of social movement restriction policies has reduced compensation, and even changes to business plans have been increasingly affected. This condition certainly provides new challenges and opportunities for SME owners. Found that to survive the new average time frame, SMEs experienced problems, such as HR limits and awareness of progress information.

Hadi \& Supardi (2020) examined restoration methods for small and medium enterprises after the COVID-19 contamination disease pandemic in Yogyakarta. This paper discusses a practical and sensible remodeling method game plan for SMEs after a pandemic. This pilot project for developing the innovative SME industry focal point business movement deserves to be maintained by all minions. This is to get maintenance from business travel accessories, travel organizers, leisure, educational institutions, money-related foundations, environmental organizations, guarantees, and competitors' cooperation. Assessment revolves around the Yogyakarta domain in the pandemic arena with a policy plan for social isolation and physical destruction with targets for social distancing and physical distancing.

Kuckertz et al. (2020) examine new small businesses amid crisis - the rapid response to the COVID-19 Pandemic. The disclosure of SARS-CoV-2 and the spread of COVID-19 have prompted various organizations to take unusual actions. The lockdown of large parts of society and life-related to money has been an exogenous shock to many monetary actors, including creative new small businesses. This rapid response research combines emotional inquiry settings taught by ambitious organic framework practitioners with methodological measures of as sessment demanded, spoken, and purportedly realized in the press worldwide. The ambitious climate summit offers a hands-on account of the difficulties new organizations face during crises and how, by harnessing their tailored bricolage responses, an assessment of methodological measures can be used as inspiration for training maintenance arrangements to protect new organizations from results. From the current lockdown and to facilitate the effects of future crises, businesses' survival is essential.

Kulkarni \& Anantharama (2020) findings on the impact of the COVID-19 Pandemic on the market's general cleaning service business: a challenge and an opportunity. The study evaluates winning metropolitan solid waste 
(MSW) board practices in specific created and agricultural countries. The data and information used in this paper were collected from several plausible assessment papers from different controls. The paper recommends an alternative approach to the treatment and evacuation of MSW. It maps future work levels to achieve a down-to-earth organization of waste during and the consequences of the Pandemic. The review also presents challenges and opportunities in a pandemic and its consistent outcomes. This paper recommends alternatives to the current public waste treatment and the funding mastermind structure so that these public cleaning services can be sustainable.

That is also the finding of Sharma (2020) who examines and examines Covid as a challenge and opportunity for Small and Medium Enterprises (SMEs). The world has grappled with COVID-19 since December 2019. For example, weakness areas are almost non-existent, and intermediate efforts have shown some signs, such as the end or severe disaster due to lockdowns in various countries. Limited financial and non-financial resources represent SMEs. This makes SMEs more inclined to the adverse effects of biological factors. The current paper examines the problems and loopholes that COVIid-19 provides for medium-sized enterprises in India. Get the latest news about Covid, COVIID-19, and other pandemic diseases here. For personal assistance with an explosion, problems contact the Samaritan on 08457909090 or visit the local Samaria branch.

Papadopoulos et al. (2020) examine the use of cutting-edge developments by small and medium-sized businesses during COVID-19: Implications for speculation and practice. Analysts have included Digital Technology (TD) in updating productivity and implementation in Small and Medium Enterprises (SMEs). However, there is limited confirmation of using DT to deal with the outcome of an unusual event, for example, COVID-19. We talk about this opening by (I) spreading the avenues of potential assessment and (ii) pondering the managerial implications of using DT in SMEs to deal with the impact of COVID-19 and achieve business fit.

Shaikh et al. (2018) examined Small and Medium Enterprises and Cloud Technology - Challenges and Opportunities during COVID19. Small and medium-sized businesses were seriously affected during the Pandemic for multi-stretch reasons. Offering programming as a service (SaaS) has proven to be more profitable for SMEs. This pandemic period also caused CSPs to improvise their organizations. The opportunity has arrived to embrace the cloud's advancement by SMBs who have not yet considered cloud deployment as a decision. A cloud-based workforce collaboration mechanical assembly and constant inaccessibility moderate critical threats during the event of a disaster. The COVID-19 Pandemic has opened up new opportunities for cloud advancement in the area of clinical considerations. The new regular has brought in less social contact, and more work advancement suggests consistent cooperation. Cloud development has become part of organizing business movements and bringing new perspectives during the Pandemic.

Kaberia \& Muathe (2021) study the impact of the COVID-19 Pandemic on the performance of micro, small and medium-sized enterprises owned by women in Kenya. The effects of the COVID-19 Pandemic are finding a way to halt the significant increases made so far. Overall, safeguard trading slumped into a motivator of about US \$ 6 trillion in less than seven days. The Pandemic is slowing down Kenya's projected GDP improvement. The most affected are Micro, Small, and Medium Enterprises. Women have associations that need not be affected by the Pandemic. The assessment recommends focusing on methodologies, investigations, and brokering resources to assist small businesses in preparing for a recurrence of such infections through the emergence of a similar or new pandemic in the future. From the beginning of the danger of prosperity, a pandemic is rapidly turning into a double risk that will uproot lives and jobs.

Korankye et al. (2020) examine the impact of the global COVID-19 Pandemic on Small and Medium-sized Enterprises in Ghana was useful. COVID-19, which is articulated as a pandemic by the World Health Organization, has affected associations, jobs, and economies. Research results show that SMEs are struggling to make because, at the moment, This Pandemic, such as a reduction in wages, scaling back, a downturn in the mainstream, a progressive remake, and the fear of leaving, are firmly linked to showing the SME domain in Kumasi Metropolis. This concludes that the Coronavirus has affected the tasks of small and medium businesses. Therefore, It should start evaluating what will make them successful and post-pin to 19 .

Priyono et al. (2020) perceive the SME business model's digital transformation pathway during the COVID-19 Pandemic. This study separates how small and medium enterprises (SMEs) adjust to regular changes due to the COVID-19 Pandemic. This exam uses various logical investigation plans with abstract assessments to break down the data gleaned from meetings, insights, and field visits. Seven SME collectors from Indonesia were selected using speculative testing techniques for losses. 
Discussion

This section discusses the review study's findings to seek a new understanding of MSME activists' challenges and opportunities after being hit by COVID-19 in many regions in Indonesia. In general, the majority of findings and results of studies from several papers and literature that we have reviewed have confirmed that small business players in many places have responded to the development and continuation of the MSMEs they manage after being hit by COVID-19. They respond on average by utilizing the technological innovation in their business, working, and serving consumers. For example, they hear digital business management experts' opinions, so they immediately adopt the business with digital innovation to respond and serve consumers utilizing online and door-to-door delivery. This method turned out to be accurate, as studied by Budiarto et al. (2018) in their paper on the development of MSMEs between conceptual and practical field experiences towards business sustainability.

In addition to digital adoption solutions in MSMEs, some receive assistance from the government based on compensation to continue to be capitalized and survive even if the funds are not too large. In essence, many MSMEs have used various ways to feel the impact of COVID-19 into a problem and the opportunity to change with all their future efforts so that they are better prepared to face another possible crisis. This study also received a response from a study by Nuvriasari (2012) in its role of organizational support, technological competence, and the external environment to assist in adopting MSME E-Commerce in regions throughout the country.

Apart from the excess of the findings data, this study's findings are also inseparable from shortcomings that require improvement and refinement support. Based on the findings data, this result study's weakness is in the design research analysis and secondary data review. Likewise, other limitations include data participation methods and instruments, where we rely on data from previous studies. Therefore, improvements to the data collection method and data analysis must involve qualitative and qualitative data so that the study results will be more balanced and varied. This is consistent with Ochieng (2009) findings, who successfully analyzed the strengths and limitations of qualitative and quantitative research paradigms.

\section{Conclusion}

We can conclude that the efforts to seek a new understanding of driving MSMEs after being hit by COVID-19 include; governments in many countries that have helped and supported MSME players' various opportunities to defend their businesses from the potential be impacted by the Pandemic. Full attention to MSMEs from the government to assist business actors in funding subsidies and providing additional working capital loans. Another opportunity for them is training in Micro, Small, and Medium Enterprises to go Online together in 30 cities or districts in Indonesia to make Indonesia the Digital Energy of Asia. Small businesses' challenge is how to deal with solutions in filling domestic and global market needs, how small businesses can have an entrepreneurial strategy based on IT (Information Technology), and maintain local wisdom. The opportunities these sharing parties have provided are expected to be helpful and beneficial to business actors in the midst of the outbreak.

Meanwhile, in facing the challenges of MSMEs, the essential thing is to build and shape the soul and potential of entrepreneurship because they do not have the soul and potential for entrepreneurship. The enthusiasm and motivation to become entrepreneurs are challenging to develop; besides the introduction and use of information technology that has entered the digitalization era, it is a challenge for MSME players to be technology literate and compete in the e-commerce market. Another challenge is that MSME players must maintain local wisdom so that the archipelago culture and love for domestic production remain a priority so that by-products from abroad do not invade the market in Indonesia. The slow growth and development of MSMEs, which have an impact on the low economic growth of the community, can lead to a decrease in the purchasing power of the community and a decrease in production for the people's economy, which in turn will lead to the inability to fulfill their daily needs, especially the basic needs of society.

\section{Acknowledgments}

We, the authors, would like to thank all those involved in supporting various academic supports so that this paper can be prepared as expected. Likewise, without the support of funding from the donor budget from our foundation, we are in charge; we are very grateful and also for all consultation services and editing of this paper, we will never forget it. 


\section{References}

Amalia, A., \& Suprayogi, M. S. (2019). Social Media Chatbots for Collaborated Engagement Marketing. CHANNEL: Jurnal Komunikasi, 7(1), 33-42. https://doi.org/10.12928/channel.v7i1.13015

Aslan. (2019). Peran Pola Asuh Orangtua di Era Digital. Jurnal Studia Insania, 7(1), 20-34. http://dx.doi.org/10.18592/jsi.v7i1.2269

Bernard, H. R., Wutich, A., \& Ryan, G. W. (2016). Analyzing qualitative data: Systematic approaches. SAGE publications.

Bagudu, H. D., Khan, S. J. M., \& Roslan, A. H. (2016). The impact of microfinance institution on development of small and medium enterprises: a case study of lagos state. International research journal of management, IT and social sciences, 3(9), 95-106.

Blandina, S., Fitrian, A. N., \& Septiyani, W. (2020). Strategi Menghindarkan Indonesia dari Ancaman Resesi Ekonomi di Masa Pandemi. Efektor, 7(2), 181-190.

Bernroider, E. (2002). Factors in SWOT Analysis Applied to Micro, Small-to-Medium, and Large Software Enterprises:: an Austrian Study. European management journal, 20(5), 562-573. https://doi.org/10.1016/S02632373(02)00095-6

Budiarto, R., Putero, S. H., Suyatna, H., Astuti, P., Saptoadi, H., Ridwan, M. M., \& Susilo, B. (2018). Pengembangan UMKM Antara Konseptual dan Pengalaman Praktis. UGM PRESS.

Dengada, R. G. (2020). Challenges and Opportunities of Micro Small and Medium Enterprises in Gujarat.

Diah, A. M., La Ode Hasiara, R., \& Irwan, M. (2020). Employee Retention of Pharmaceutical Firms in Indonesia: Taking Investment in Employee Development and Social and Economic Exchange as Predictors. Systematic Reviews in Pharmacy, 11(1), 564-572.

Dwivedi, Y. K., Hughes, D. L., Coombs, C., Constantiou, I., Duan, Y., Edwards, J. S., Gupta, B., Lal, B., Misra, S., \& Prashant, P. (2020). Impact of COVID-19 pandemic on information management research and practice: Transforming education, work and life. International Journal of Information Management, 55, 102211.

Effendi, M. I., Sugandini, D., \& Istanto, Y. (2020). Social Media Adoption in SMEs Impacted by COVID-19: The TOE Model. The Journal of Asian Finance, Economics, and Business, 7(11), 915-925.

Eggers, F. (2020). Masters of disasters? Challenges and opportunities for SMEs in times of crisis. Journal of Business Research, 116, 199-208.

Gunawan, H., Sinaga, B. L., \& WP, S. P. (2019). Assessment of the readiness of micro, small and medium enterprises in using E-money using the unified theory of acceptance and use of technology (UTAUT) method. Procedia Computer Science, 161, 316-323. https://doi.org/10.1016/j.procs.2019.11.129

Esubalew, A. A., \& Raghurama, A. (2020). The mediating effect of entrepreneurs' competency on the relationship between Bank finance and performance of micro, small, and medium enterprises (MSMEs). European Research on Management and Business Economics, 26(2), 87-95. https://doi.org/10.1016/j.iedeen.2020.03.001

Endraswati, H. (2020). Pandemi covid-19 dan strategi bagi umkm: perspektif marketing dan keuangan. covid-19 dan transformasi keberagamaan, 76.

Eriksson, P., \& Kovalainen, A. (2015). Qualitative methods in business research: A practical guide to social research. Sage.

Hadi, S., \& Supardi, S. (2020). Revitalization strategy for small and medium enterprises after Corona virus disease pandemic (covid-19) in Yogyakarta. J. Xian Univ. Archit. Technol, 12, 4068-4076.

Heinonen, K., \& Strandvik, T. (2020). Reframing service innovation: COVID-19 as a catalyst for imposed service innovation. Journal of Service Management.

Hyder, A., Mahmood, Z., Ullah, W., Anjum, G., Nakhoda, A., Shabbar, S., Iqbal, N., \& Khalid, S. (2020). eBook Short Notes on the Economy during the COVID-19 Crisis. Vol-Ii. Vol-Ii (June 21, 2020).

Islam, A., Jerin, I., Hafiz, N., Nimfa, D. T., \& Wahab, S. A. (2021). Configuring a blueprint for Malaysian SMEs to survive through the COVID-19 crisis: The reinforcement of Quadruple Helix Innovation Model. Journal of Entrepreneurship, Business and Economics, 9(1), 32-81.

Iwuoha, V. C., \& Aniche, E. T. (2020). Covid-19 lockdown and physical distancing policies are elitist: Towards an indigenous (Afro-centred) approach to containing the pandemic in sub-urban slums in Nigeria. Local Environment, 25(8), 631-640.

Kaberia, S. K., \& Muathe, S. M. (2021). Effect of Covid-19 Pandemic on Performance of Women Owned Micro, Small and Medium Enterprises in Kenya. International Journal of Social Science Studies, 9(1), 7-21.

Korankye, B., Wen, X., Michael, A., \& Baah-Nketiah, E. (2020). Analyzing Economic Growth and Its impact on Poverty Reduction in Africa. International Journal of Science and Business, 4(12), 93-105. 
Kottika, E., Özsomer, A., Rydén, P., Theodorakis, I. G., Kaminakis, K., Kottikas, K. G., \& Stathakopoulos, V. (2020). We survived this! What managers could learn from SMEs who successfully navigated the Greek economic crisis. Industrial Marketing Management, 88, 352-365.

Kuckertz, A., Brändle, L., Gaudig, A., Hinderer, S., Morales Reyes, C. A., Prochotta, A., Steinbrink, K. M., \& Berger, E. S. C. (2020). Startups in times of crisis - A rapid response to the COVID-19 pandemic. Journal of Business Venturing Insights, 13, e00169. https://doi.org/10.1016/j.jbvi.2020.e00169

Khanzode, A. G., Sarma, P. R. S., Mangla, S. K., \& Yuan, H. (2021). Modeling the Industry 4.0 adoption for sustainable production in Micro, Small \& Medium Enterprises. Journal of Cleaner Production, $279,123489$. https://doi.org/10.1016/j.jclepro.2020.123489

Kulkarni, B. N., \& Anantharama, V. (2020). Repercussions of COVID-19 pandemic on municipal solid waste management: Challenges and opportunities. Science of the Total Environment, 743, 140693.

Kumar, A., \& Ayedee, D. (2021). Technology Adoption: A Solution for SMEs to Overcome Problems during COVID-19. Forthcoming, Academy of Marketing Studies Journal, 25(1).

Leeflang, P. S., Verhoef, P. C., Dahlström, P., \& Freundt, T. (2014). Challenges and solutions for marketing in a digital era. European Management Journal, 32(1), 1-12.

Morrish, S. C., \& Jones, R. (2020). Post-disaster business recovery: An entrepreneurial marketing perspective. Journal of Business Research, 113, 83-92.

Nuvriasari, A. (2012). Peran Dukungan Organisasional, Kompetensi Teknologi dan Lingkungan Eksternal Dalam Rangka Mendorong Pengadopsian E-Commerce Pada usaha Kecil Menengah. Jurnal Siasat Bisnis, 16(2).

Ochieng, P. A. (2009). An analysis of the strengths and limitation of qualitative and quantitative research paradigms. Problems of Education in the 21st Century, 13, 13.

Papadopoulos, T., Baltas, K. N., \& Balta, M. E. (2020). The use of digital technologies by small and medium enterprises during COVID-19: Implications for theory and practice. International Journal of Information Management, 55, 102192.

Pindayi, B. (2017). Social media uses and effects: The case of Whatsapp in Africa. In Impacts of the media on African socio-economic development (pp. 34-51). IGI Global.

Priyono, A., Moin, A., \& Putri, V. N. A. O. (2020). Identifying Digital Transformation Paths in the Business Model of SMEs during the COVID-19 Pandemic. Journal of Open Innovation: Technology, Market, and Complexity, 6(4), 104.

Putra, P., Liriwati, F. Y., Tahrim, T., Syafrudin, S., \& Aslan, A. (2020). The Students Learning from Home Experiences during Covid-19 School Closures Policy In Indonesia. Jurnal Iqra' : Kajian Ilmu Pendidikan, 5(2), 30-42. https://doi.org/10.25217/ji.v5i2.1019

Radic, A., Lück, M., Ariza-Montes, A., \& Han, H. (2020). Fear and trembling of cruise ship employees: Psychological effects of the COVID-19 pandemic. International Journal of Environmental Research and Public Health, 17(18), 6741.

Rizou, M., Galanakis, I. M., Aldawoud, T. M., \& Galanakis, C. M. (2020). Safety of foods, food supply chain and environment within the COVID-19 pandemic. Trends in Food Science \& Technology, 102, 293-299.

Shafi, M., Liu, J., \& Ren, W. (2020). Impact of COVID-19 pandemic on micro, small, and medium-sized Enterprises operating in Pakistan. Research in Globalization, 2, 100018.

Syuhada, A. A., \& Gambett, W. (2013). Online marketplace for Indonesian micro small and medium enterprises based on social media. Procedia Technology, 11, 446-454. https://doi.org/10.1016/j.protcy.2013.12.214

Shaikh, M., Woodward, M., John, O., Bassi, A., Jan, S., Sahay, M., Taduri, G., Gallagher, M., Knight, J., \& Jha, V. (2018). Utilization, costs, and outcomes for patients receiving publicly funded hemodialysis in India. Kidney International, 94(3), 440-445.

Sharma, N. (2020). COVID-19: Challenges and Opportunities for Small and Medium Enterprises (SMEs). Available at SSRN 3650473.

Samantha, G. (2018). The impact of natural disasters on micro, small and medium enterprises (MSMEs): a case study on 2016 flood event in Western Sri Lanka. Procedia engineering, 212, 744-751. https://doi.org/10.1016/j.proeng.2018.01.096

Soetjipto, N. (2020). Ketahanan UMKM Jawa Timur Melintasi Pandemi Covid-19. K-Media.

Suci, Y. R. (2017). Perkembangan UMKM (Usaha mikro kecil dan menengah) di Indonesia. Cano Ekonomos, 6(1), 51-58.

Sugiri, D. (2020). Menyelamatkan usaha mikro, kecil dan menengah dari dampak pandemi Covid-19. Fokus Bisnis: Media Pengkajian Manajemen Dan Akuntansi, 19(1), 76-86. 
Wisenthige, K., \& Guoping, C. (2016). Firm level competitiveness of small and medium enterprises (SMEs): analytical framework based on pillars of competitiveness model. International research journal of management, IT and social sciences, 3(9), 61-67.

Zakiah, S. et, al. (2020). Social media as an effective tourism marketing in the digital era. International Journal of Advanced Science and Technology, 29(2), 753-766. 